\title{
PRIKLAUSOMYBE NUO ALKOHOLIO TURINČIŲ PACIENTŲ SLAUGOS POREIKIAI: SLAUGYTOJŲ IR PACIENTŲ NUOMONĖS TYRIMAS
}

\author{
Ana Kikiličiené $\dot{e}^{1,2}$, Kastytis Dapšys ${ }^{1}$ \\ ${ }^{1}$ Sšl Respublikine Vilniaus psichiatrijos ligonine, \\ ${ }^{2}$ Lietuvos sveikatos mokslu universiteto Slaugos ir rūpybos katedra
}

Raktažodžiai: slaugos poreikiai, priklausomybė nuo alkoholio, komforto teorija.

\begin{abstract}
Santrauka
Tyrimo tikslas buvo ištirti priklausomybę nuo alkoholio turinčiu pacientų slaugos poreikius. Tyrime dalyvavo 89 pacientai, turintys priklausomybę nuo alkoholio ir 103 slaugytojai, dirbantys RVPL su tokiais pacientais. Atliktas kiekybinio tyrimo metodas - anketavimas. Tyrimui buvo pritaikyta anoniminè anketa, sudaryta remiantis D. Drungilienès ir kt. (2011) tyrimo instrumentu, skirtu pacientų, turinčių priklausomybę nuo opioidų lūkesčiams tirti. Tyrimo rezultatai parodè, kad skyriaus aplinką didžioji pacientų dalis vertino patenkinamai, tuo tarpu slaugytojos dažniausiai aplinką vertino gerai arba labai gerai. Anot pacientų ir slaugytojų, daugiausia ịtakos slaugos kokybei skyriuje turi mokejjimas atlikti slaugos procedūras ir nuolatinis slaugytojo kvalifikacijos kélimas. Slaugytojai savo profesionalumą vertina šiek tiek geriau, nei pacientai, taip pat slaugytojams dažniau nei pacientams atrodo, kad jie laikosi profesinès etikos. Slaugytojams dažniau atrodo, kad pacientai labiau patenkinti teikiamomis paslaugomis, nei jie yra iš tikrujų, taip pat slaugytojai savo elgesi su pacientais vertina geriau nei pacientai. Jiems slaugytojų elgesys dažniau atrodo neutralus. Slaugytojams dažniau nei pacientams atrodo, kad jie užtikrina pacientų teisę i privatumą ir konfidencialumą, taip pat slaugytojams labiau nei pacientams atrodo, kad jie gerbia visus pacientus, jų asmeninius įpročius, rūpinasi jų saugumu, geranoriškai bendrauja su kolegomis, sugeba bendrauti su pacientais ir jų šeimos nariais bei stengiasi juos itraukti i slaugos procesą. Tuo tarpu pacientams labiau nei slaugytojams atrodo, kad slaugytojai teikia
\end{abstract}

pirmumą kai kuriems pacientams. Slaugytojai geriau nei pacientai vertina savo asmenines savybes, bendraujant su pacientais. Apibendrinant galima daryti išvadą, kad fiziniai pacientų slaugos poreikiai patenkinami geriau nei funkciniai bei socialiniai.

\section{Ivadas}

Slaugytojų darbas ịvairiose medicinos srityse turi daug bendru ypatumų, bet skiriasi savo specifika, nes tai sąlygoja skirtingi pacientu poreikiai. Darbas su nuo alkoholio priklausomybę turinčiais pacientais yra individualus, komfortas yra būtinas komponentas optimaliai palaikyti biologines, psichologines ir socialines funkcijas $[1,5,6]$. Didelè atsakomybè slaugytojams tenka nustatant pacientų, sergančių alkoholine psichoze, slaugos poreikius [3]. Lietuvoje nèra atlikta slaugos mokslinių darbų, kurie vertintų pacientų, turinčių priklausomybę nuo alkoholio, poreikius ne tik iš paciento, bet ir iš slaugytojų pozicijos [7]. Nèra sukurta ar/ir adaptuota instrumentų, galinčių nustatyti paciento, turinčio priklausomybę nuo alkoholio, poreikius. Slaugos poreikių nustatymas padètų slaugytojai identifikuoti slaugos problemą ir vėliau planuoti tokių pacientu ilgalaikę kompleksinę slaugą, t.y. slaugos procesu būtų kuriamas nuolatinis komfortas. Todèl priklausomybès ligu specialistai yra svarbi grandis tarp priklausomų asmenų ir visuomenès [2,4].

Tyrimo tikslas: ištirti priklausomybę nuo alkoholio turinčių pacientų slaugos poreikius.

\section{Metodai}

Tyrimas buvo vykdomas $2014 \mathrm{~m}$. kovo - $2015 \mathrm{~m}$. sausio mèn. Respublikinèje Vilniaus psichiatrijos ligoninèje (RVPL). Atliktas kiekybinio tyrimo metodas - anketavimas. Tyrimui buvo pritaikyta anoniminè anketa, sudaryta remiantis D. Drungilienès ir kt. (2011) tyrimo instrumentu, skirtu pacientų, turinčiu priklausomybę nuo opioidų, lū- 
kesčiams tirti [2]. Tyrime dalyvavo 89 pacientai, turintys priklausomybę nuo alkoholio ir 103 slaugytojai, dirbantys RVPL su tokiais pacientais. Anketoje pacientams pateiktas 21 standartizuotas klausimas, o slaugytojams - 25 klausimai (kai kurie klausimai vienodi tiek slaugytojams, tiek pacientams). Pacientų slaugos poreikiai skirstomi į fizinius (1 klausimas, kuris apème 4 aplinkos faktorius), funkcinius (2-9 klausimai) ir socialinius (10-14 klausimai). Kiti klausimai buvo sociodemografiniai. Kaip tenkinami ịvairūs poreikiai, pacientams reikejo įvertinti nuo 1 (labai blogai) iki 5 (labai gerai). Tyrimo duomenų analizei atlikti naudotos SPSS 22 ir Office Excel 2007 programos. Pacientų ir slaugytojų požiūrių lyginimui naudoti neparametriniai MannWhitney ir chi kvadrato $\left(\chi^{2}\right)$ kriterijai dviem nepriklausomoms imtims.

Tyrimui vykdyti buvo gautas Lietuvos sveikatos mokslų universiteto Bioetikos centro leidimas Nr. BECKS(M)-239.

\section{Tyrimo rezultatai}

Daugiausia pacientų buvo 20-30 metų amžiaus grupès (38 proc.), mažiausiai per 60 metu amžiaus grupés (2 proc.). Daugiau moteru (61 proc.), nei vyru (39 proc.).

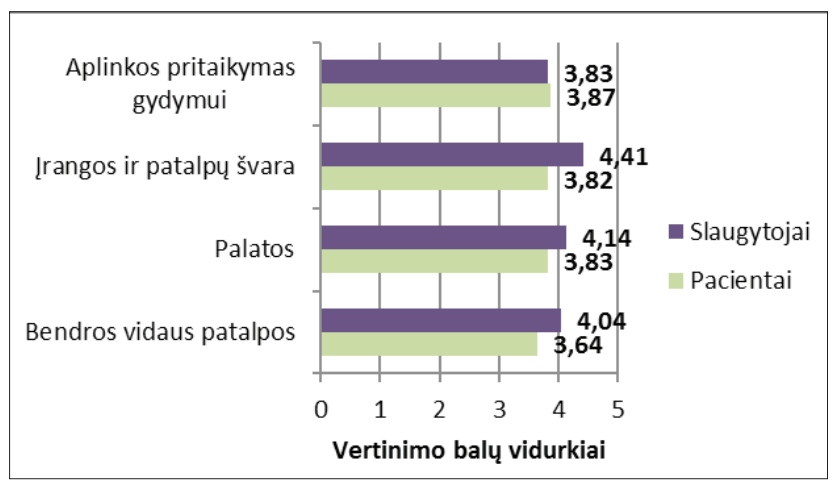

1 pav. Skyriaus aplinkos ịvertinimo palyginimas tarp slaugytojų ir pacientų

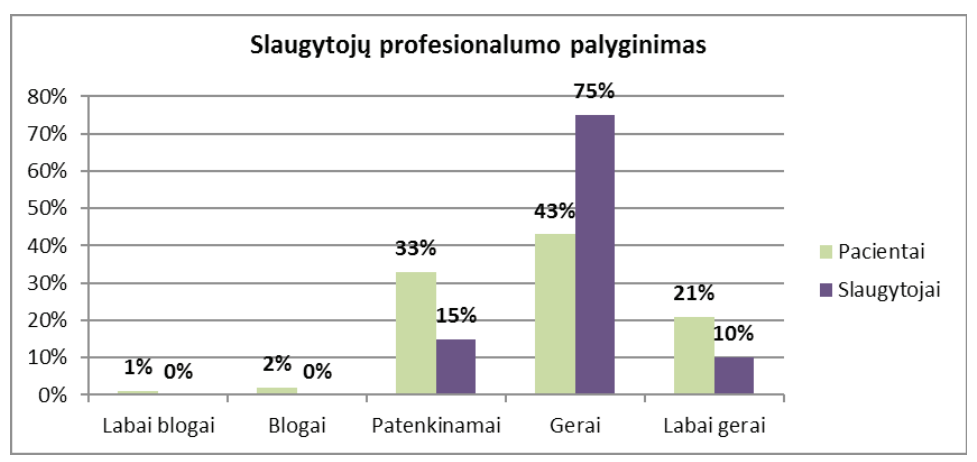

2 pav. Slaugytojų profesionalumo ịvertinimo palyginimas
Slaugytojų amžius svyravo nuo 23 iki 70 metų amžiaus, amžiaus vidurkis $-45 \pm 10,2$. Didžiausią grupę sudare 41 50 metų amžiaus (35 proc.), mažiausią - per 60 metų amžiaus slaugytojos (8 proc.). 95 proc. slaugytoju - moterys.

Pirmiausia buvo ịvertinti pacientu fiziniai, funkciniai bei socialiniai slaugos poreikiai bendrai. Fizinių slaugos poreikių vertinimo vidurkis buvo $3,79 \pm 0,75$ balo, funkcinių poreikiu $-3,72 \pm 0,69$ balo, socialiniu poreikiu $-3,73 \pm 0,65$ balo. Panašu, kad fiziniai pacientų slaugos poreikiai patenkinami geriausiai.

Vertinant skyriaus aplinką, didžioji pacientų dalis ją vertino patenkinamai (36-51 proc.), tuo tarpu slaugytojos dažniausiai aplinką, tiek bendras patalpas, palatas ir apskritai švarą vertino gerai arba labai gerai (40-90 proc.). Rezultatai rodo, kad slaugytojos statistiškai reikšmingai $(\mathrm{p}<0,05)$ geriau nei pacientai vertina bendras vidaus patalpas, palatas bei ịrangos ir patalpų švarą (1 pav.).

Didžioji dalis tiek pacientų (64 proc.), tiek slaugytojų (86 proc.) vertina slaugytojų profesionalumą gerai arba labai gerai. Palyginus jų ịvertinimus tarpusavyje, paaiškèjo, kad statistiškai reikšmingai $\left(\mathrm{p}=0,000 ; \chi^{2}(2)=21,910\right)$ slaugytojos geriau vertina savo profesionalumą, nei pacientai (2 pav.).

Anot pacientų, daugiausia įtakos slaugos kokybei skyriuje iš visų išvardintų aplinkybių turi mokejjimas atlikti slaugos procedūras ir nuolatinis slaugytojo kvalifikacijos kèlimas. Slaugytojoms taip pat atrodo, kad daugiausia įtakos slaugos kokybei turi mokèjimas atlikti slaugos procedūras. Apskritai, slaugytojams visos išvardintos aplinkybės statistiškai reikšmingai $(\mathrm{p}<0,05)$ atrodo turinčios daugiau itakos slaugos kokybei, nei taip atrodo pacientams.

Kalbant apie profesinę etiką ir teisę ị pacientų privatumą, didžioji dalis slaugytojų teigè, kad jie visada, ar beveik visada laikosi profesinès etikos (99 proc.). 34 proc. pacientų atrodo, kad slaugytojos kartais laikosi etikos, kartais ne. Vèlgi, slaugytojoms statistiškai reikšmingai $(\mathrm{p}=0,000$; $\left.\chi^{2}(2)=57,217\right)$ dažniau nei pacientams atrodo, kad jos laikosi profesinès etikos (3 pav.).

Didžiajai daliai (94 proc.) slaugytojų taip pat atrodo, kad jie užtikrina pacientų teisę i privatumą ir konfidencialumą, o 40 proc. pacientų atrodo, kad teisę i privatumą slaugytojai užtikrina tik kartais. Vèlgi, šis skirtumas yra statistiškai reikšmingas $\left(\mathrm{p}=0,000 ; \chi^{2}(2)=36,396\right)$ ( 4 pav.).

Pacientams teko ivertinti savo pasitenkinimą skyriuje teikiamomis slaugos paslaugomis, o slaugytojams - iqvertinti, kiek patenkinti slaugos paslaugomis yra pacientai. Statistiškai reikšmingai $\left(p=0,000 ; \chi^{2}(2)=38,216\right)$ slaugytojams atrodo, kad pacientai labiau patenkinti teikiamomis 
paslaugomis, nei jos yra iš tikrujų (5 pav.).

Ivertinus skyriaus slaugytojų elgesị, slaugant pacientus ir palyginus slaugytojų ir pacientu vertinimus, taip pat gauti statistiškai reikšmingi skirtumai $\left(\mathrm{p}=0,000 ; \chi^{2}(2)\right.$ $=24,819)$. Slaugytojai savo elgesi su pacientais vertina geriau nei pacientai. Jiems slaugytojų elgesys dažniau atrodo neutralus, nei blogas, nei geras (6 pav.).

Dirbančių skyriuje slaugytojų gebejjimą bendrauti slaugos proceso metu pacientai dažniausiai vertino teigiamai, nors maždaug trečdalis pacientų teigè, kad tokiu elgesiu slaugytojai pasižymi tik kartais. Slaugytojai priešingai, beveik visu 100 proc. teige, kad jie visada arba beveik visada gerbia pacientus, rūpinasi jais ir sugeba bendrauti. Statistiškai reikšmingai $(p<0,05)$ slaugytojams labiau nei pacientams atrodo, kad jie gerbia visus pacientus, jų asmeninius ịpročius, rūpinasi jų saugumu, geranoriškai bendrauja su kolegomis, sugeba bendrauti su pacientais ir jų šeimos nariais bei stengiasi juos įtraukti ị slaugos procesą. Tuo tarpu pacientams labiau nei slaugytojams atrodo, kad slaugytojai teikia pirmumą kai kuriems pacientams (7 pav.).

Panašūs skirtumai gauti ir palyginus slaugytojų bei pacientų skyriaus slaugytojų asmeninių savybių, bendraujant su pacientais, vertinimą. Slaugytojos statistiškai reikšmingai $(\mathrm{p}<0,05)$ geriau nei pacientai vertina savo asmenines savybes, bendraujant su pacientais (8 pav.).

\section{Rezultatų aptarimas}

Rezultatai rodo, kad fizinius slaugos poreikius pacientai ìvertino aukštesniais balais, nei funkcinius ir socialinius, nors fizinę skyriaus aplinką didžioji dalis pacientų vertino patenkinamai. Svarbus faktorius, lemiantis paciento fizinę ir psichologinę būseną bei stipriai turintis įtakos sèkmingam jo sveikimo procesui yra komfortas. K. Kolcaba (2004) nurodo, kad aplinka (temperatūra, šviesa, garsai, kvapai, spalva, baldai ir kiti žmogaus patirties faktoriai) yra labai svarbi komforto sudètinè dalis. Galbūt, jau šioks toks nepasitenkinimas skyriaus aplinka, turi itakos mažesniam pasitenkinimui slauga apskritai. Kaip matyt iš rezulpalyginimas

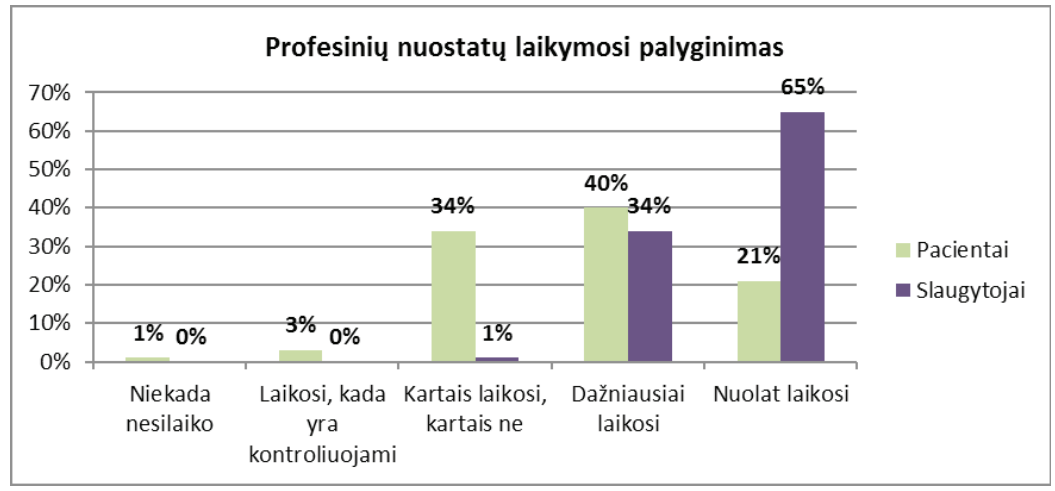

3 pav. Profesinès etikos nuostatų laikymosi palyginimas

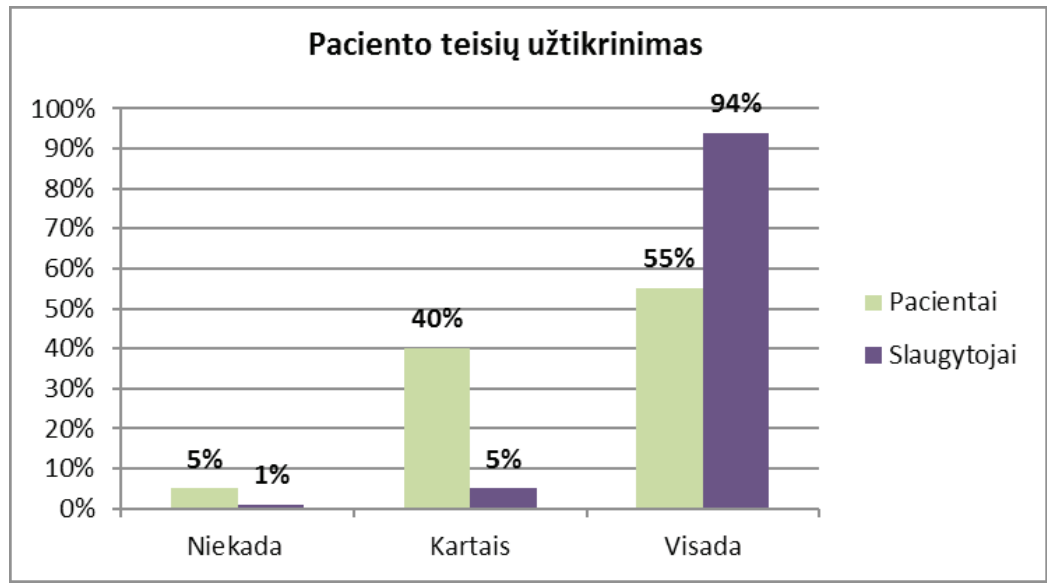

4 pav. Nuomonių dèl paciento teisių ị privatumą ir konfidencialumą užtikrinimo

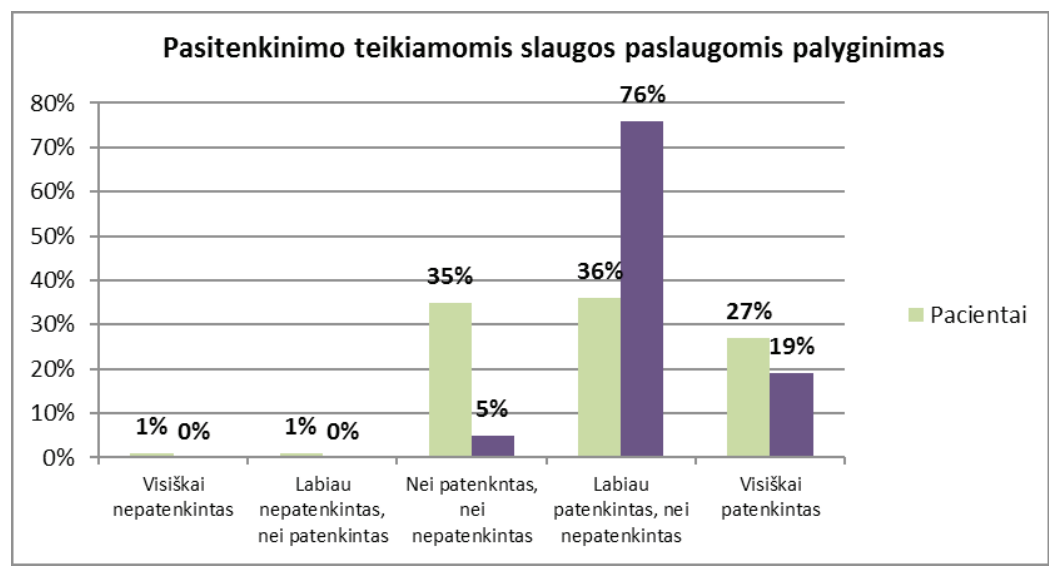

5 pav. Pasitenkinimo teikiamomis slaugos paslaugomis palyginimas

tatų, pacientai prasčiau nei slaugytojai vertina tiek jų profesionalumą, tiek jų profesinès etikos nuostatų laikymąsi, gebẻjimą užtikrinti pacientų teisę ì privatumą ir konfiden- 


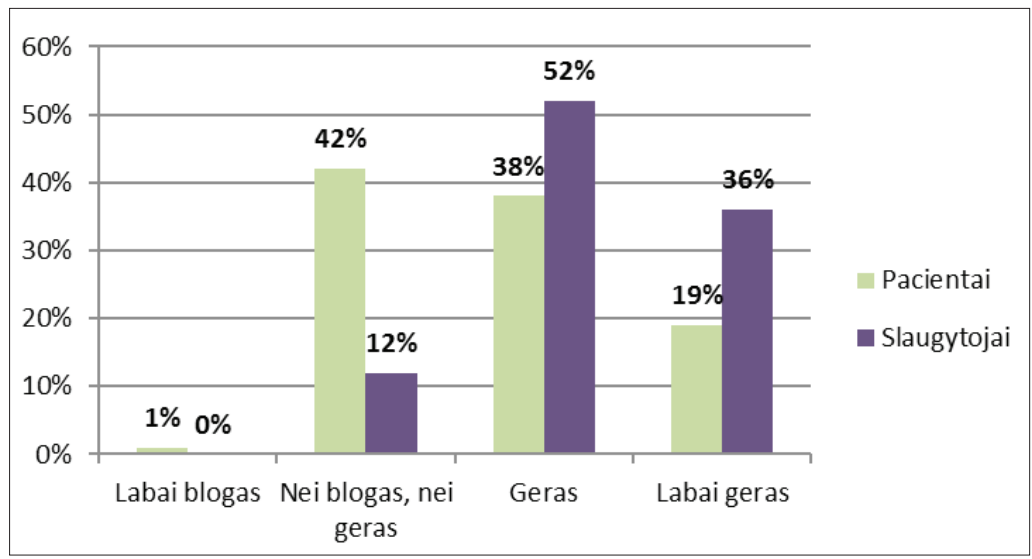

6 pav. Slaugytojų elgesio ịvertinimo palyginimas

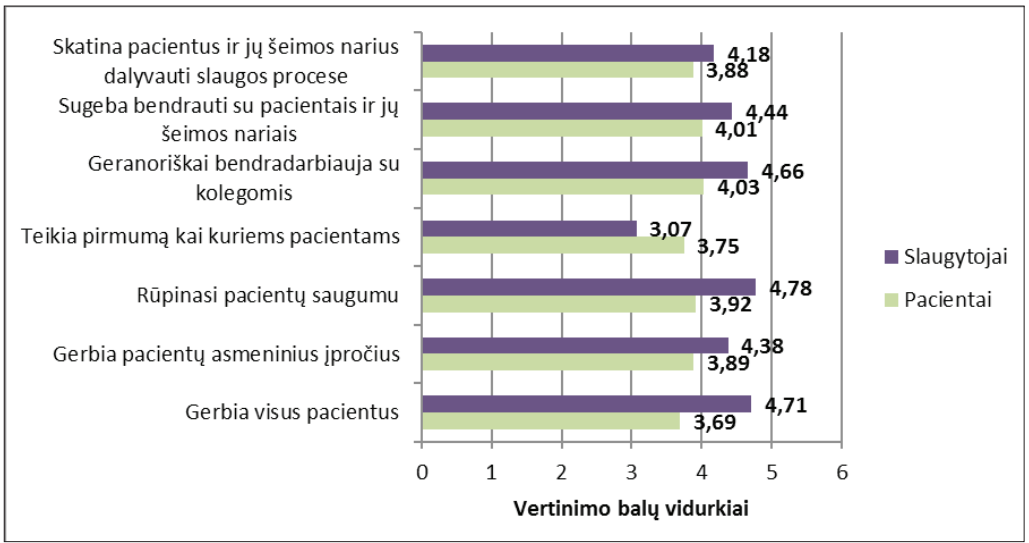

7 pav. Dirbančių skyriuje slaugytojų gebėjimo bendrauti įvertinimo palyginimas

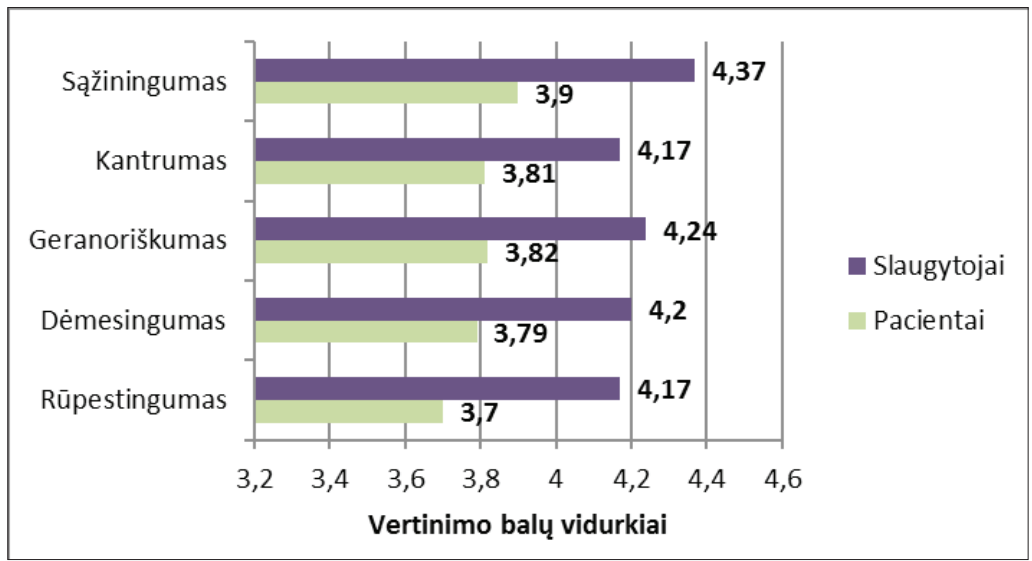

8 pav. Slaugytojų asmeninių savybių vertinimo palyginimas

cialumą, jų gebejjimą bendrauti slaugos proceso metu bei jų asmenines savybes ir apskritai yra mažiau patenkinti slaugos paslaugomis, nei atrodo slaugytojams. Aišku, komforto teorijos požiūriu fizinè ir psichinè priklausomybė nuo alkoholio yra didžiausias diskomfortas [5]. Taigi, dèl savo priklausomybès šie pacientai gali jausti daugiau diskomforto apskritai, turèti didesnius slaugos, medicininius, socialinius, psichologinius poreikius ir neicvertinti slaugytojų pastangų bei geranoriškumo. Kita vertus, galbūt dèl didesnių tokių pacientų poreikių, slaugytojai ne visada pajègūs duoti tiek, kiek jiems reikia, dèl to ir atsiranda šie skirtumai tarp slaugytojų ir pacientų slaugos kokybès vertinimų.

\section{Išvados}

1. Skyriaus aplinką didžioji pacientų dalis vertino patenkinamai, tačiau fiziniai pacientu slaugos poreikiai patenkinami geriau nei funkciniai bei socialiniai. Didžioji dalis pacientų vertina slaugytojų profesionalumą gerai arba labai gerai. Anot pacientų, daugiausia itakos slaugos kokybei skyriuje turi mokejjimas atlikti slaugos procedūras ir nuolatinis slaugytojo kvalifikacijos kèlimas. Trečdaliui pacientu atrodo, kad slaugytojos kartais laikosi etikos, kartais ne, taip pat ne visada užtikrina jų teisę ì privatumą ir konfidencialumą, jų elgesys su pacientais dažniau neutralus, ir pacientams atrodo, kad slaugytojai teikia pirmumą kai kuriems pacientams.

2. Slaugytojai skyriaus aplinką, tiek bendras patalpas, palatas ir apskritai švarą vertino gerai arba labai gerai. Gerai arba labai gerai jie vertino savo profesionalumą. Didžioji dalis slaugytojų teigè, kad jie visada ar beveik visada laikosi profesinès etikos, beveik visada užtikrina pacientų teisę i privatumą bei konfidencialumą, bei elgiasi su jais gerai arba labai gerai. Slaugytojams taip pat atrodo, kad daugiausia itakos slaugos kokybei turi mokejjimas atlikti slaugos procedūras.

3. Palyginus pacientų ir slaugytojų požiūrị i c slaugos poreikius, statistiškai reikšmingai slaugytojai geriau nei pacientai vertina savo profesionalumą, savo elgesị su pacientais, savo gebejjimą gerbti visus pacientus, jų asmeninius ịpročius, rūpintis jų saugumu, geranoriškai bendrauti su kolegomis, su pacientais ir jų šeimos nariais bei įtraukti juos i slaugos procesą, taip pat savo asmenines savybes, bendraujant su pacientais. Slau- 
gytojams dažniau nei pacientams atrodo, kad jie laikosi profesinès etikos, užtikrina pacientų teisę i privatumą ir konfidencialumą. Be to, slaugytojams dažniau nei pacientams atrodo, kad pacientai labiau patenkinti teikiamomis paslaugomis, nei yra iš tikrujjų.

\section{Literatūra}

1. DiCenso A. Roles, research and resilience: The evolution of advanced practice nursing. Canadian Nurse 2008; 104(9):3740.

2. Drungilienė D., Slatvickaja N., Žiliukas G. Slaugos paslaugu atitiktis opioidinès priklausomybès pacientų lūkesčiams. Sveikatos mokslai, 2011; 7(21): 196-201.

3. Grabauskas V., Prochorskas R., Veryga A. Lietuvos gyventojų mirtingumo sąsajos su alkoholinių gẻrimų vartojimu. Medicina, 2009; 45(12): 46-49.

4. Jasiukevičiūtė T., Danilevičiūtė V., Pajarskienẻ B. Būsimų medicininès, psichologinès ir socialinès pagalbos specialisty požiūris ị priklausomybę, besigydantis asmenis. Visuomenès sveikata, 2010; 3(50): 90-99.

5. Kolcaba K, Wilson L. Practical Application Comfort Theory in the Perianesthesia Setting. American Society of PeriAnesthesia Nurses 2004.

6. Sangster-Hormley E, Frisch N, Schreiber R. Articulating new outcomes of nurse practitioner practice. Journal of American Association of Nurse Practitioners 2013; 25:653-658.

7. Vanagas G., Padaiga Ž., Bagdonas E. Pakaitinio gydymo metadonu kaštų ir naudingumo analizė Lietuvoje. Medicina, 2010; 46(4):286-292.

\section{NURSING NEEDS OF PATIENTS WITH ALCOHOL DEPENDENCE: NURSES AND PATIENTS OPINION SURVEYS}

\section{A. Kikiličienė, K. Dapšys}

Key words: nursing needs, alcohol dependence, comfort theo-

\section{Summary}

The aim was to investigate patients with alcoholic addiction care needs. The study involved 89 patients with alcohol dependence and 103 nurses working in RVPL with such patients. A qualitative research method - questionnaire. The study was applied to an anonymous questionnaire, compiled on the basis Drungilienès D. et al. (2011) survey instrument for patients with opioid dependence investigate expectations. The results showed that the Department of Environmental majority of patients rated satisfactory, while nurses are mostly rated as good or very good. According to the patients and nurses, mainly affected by the quality of the nursing section has the ability to perform nursing procedures and permanent nurse training. Nurses appreciate your professionalism slightly better than the patients as well as nurses more patients than they appear to comply with professional ethics. Caregivers often seems that patients are more satisfied with the services than they really are, as well as their caregivers treatment of patients better than the patients. They nursing behavior often seems neutral. Caregivers are more likely than patients feel that they ensure patients' right to privacy and confidentiality, as well as nurses more patients than they appear to respect all patients and their personal habits, take care of their security, communicate with colleagues in good faith, are able to communicate with patients and their families Members and try to involve them in the care process. Meanwhile, more patients than nurses seems that nurses provide priority for some patients. Nurses better than patients assess their personal qualities in dealing with patients. In summary, it can be concluded that the physical needs of the patient better than satisfactory functional and social.

Correspondence to: aniuk83@gmail.com

Gauta 2015-04-30 ry. 